\title{
Case Report: \\ A HEADSET IN THE BLADDER
}

\section{Soetojo, Hasan Madani}

Department of Urology, Dr. Soetomo General Hospital, Faculty of Medicine, Universitas Airlangga, Surabaya, Indonesia

\section{ABSTRACT}

Foreign objects may be present in the bladder due to deliberate insertion or displacement of the surrounding organs. There have been multiple cases of sharp objects such as nails, hair pins, and screws, as well as large objects such as AAA batteries, toothbrushes, and ballpoint pens found in the urethra and the bladder, which must have been aimed to induce sexual satisfaction associated with mental and psychic disorders. The diagnosis was established by means of radiological examinations, ie thoracic $x$ ray, KUB, and urethrography. This article reported a 32-year-old man with headset inserted to penile until bladder and could not be pulled out again. The patient complained pain and bleeding out of the urinary tract. We performed vesicotomy and pulling the out headset from bladder. The operation was succesful. In conclusion, the case of a headset in the bladder has been treated successfully with vesicotomy.

Keywords: Headset in bladder; vesicotomy

\section{ABSTRAK}

Benda asing dapat hadir di kandung kemih karena penyisipan yang disengaja atau perpindahan organ di sekitarnya. Ada beberapa kasus benda tajam seperti kuku, jepit rambut, dan sekrup, serta benda besar seperti baterai AAA, sikat gigi, dan pulpen yang ditemukan di uretra dan kandung kemih, yang pastinya bertujuan untuk mendorong kepuasan seksual. terkait dengan gangguan mental dan psikis. Untuk mendiagnosis, kami melakukan pemeriksaan radiologi berupa foto polos abdomen dan thorax. Kami melaporkan pasien laki-laki berusia 32 tahun dengan keluhan headset masuk dari penis hingga buli-buli dan tidak dapat tarik keluar lagi. Pasien mengeluh nyeri dan keluar darah dari sela-sela saluran kencing. Dilakukan vesikotomi dan ekstraksi headset dari bulibuli. Operasi berjalan dengan sukses. Kesimpulan: Sebuah kasus headset dalam buli-buli telah dilakukan vesikotomi dengan hasil yang baik.

Kata kunci: Headset dalam buli-buli; vesikotomi

Correspondence: Soetojo, Department of Urology, Dr. Soetomo General Hospital, Faculty of Medicine, Universitas Airlangga, Jalan Prof dr Moestopo 6-8, Surabaya 60286, Indonesia. E-mail:

pISSN:2355-8393 • eISSN: 2599-056x • doi: http://dx.doi.org/10.20473/fmi.v55i2.14393

- Fol Med Indones. 2019;55:153-158 • Received 12 Nov 2018 • Accepted 23 May 2019

- Open access under CC-BY-NC-SA license • Available at https://e-journal.unair.ac.id/FMI/

\section{INTRODUCTION}

Organs in the urinary tract system, including male external genitalia, are protected by surrounding structures. The bladder is located behind the pelvic bone and in front of the rectum so that it cannot be accessed directly. The bladder functions as a reservoir and periodically excretes urine with a capacity between 450 $750 \mathrm{ml}$. The urethra in males has a length between 16$20 \mathrm{~cm}$ so that the presence of foreign object within is rare (Eke \& Okpani 2003). The presence of a foreign object in the bladder is caused by deliberate entry or due to the displacement of the surrounding organs. In some cases, small objects are inserted into the urethra and the bladder for sexual satisfaction, which is related to mental or psychic disorders (Kochakarn \& Pummanagura 2008, Rafique 2008).

We reported a 32-year-old male patient complaining of a headset entering through his penis to the bladder, and it was hard to pull the headset out. The patient complained pain and bleeding from the urethra. The patient came to the Emergency Unit of Dr. Soetomo Hospital, Surabaya, Indonesia. The course of this case is very interesting, because the case is rarely found.

\section{CASE REPORT}


A 32-year-old man came to the Emergency Unit of Dr. Soetomo Hospital, Surabaya, Indonesia. The patient complained about a headset entering his penis up to the bladder and could not be pulled out. The patient also felt pain in the penis and blood discharged from the urethra. The patient did not have a history of treatment for mental disorders and did not have a history of previous similar events.

On physical examination, the patient showed stable general and hemodynamic state. Injury was not found on the left-right waist, abdomen, or other limbs. The patient was consulted to the Department of Psychiatry at the Emergency Unit of dr. Soetomo Hospital, with the result that the patient had obsessive compulsive disorder and received psychopharmacy clobazam $2 \times 5 \mathrm{mg}$. The patient also received supportive psychotherapy.

Blood laboratory examination at the Emergency Unit of dr. Soetomo Hospital showed hemoglobin of $14.5 \mathrm{~g} / \mathrm{dL}$, leukocytes $14.19 * 103 / \mathrm{uL}$, platelets $369 * 103 / \mathrm{uL}$ with normal kidney function, blood urea nitrogen (BUN) 14 $\mathrm{mg} / \mathrm{dl}$, and serum creatinine $0.92 \mathrm{mg} / \mathrm{dl}$. Urinalysis showed ph 5.5, 5-10/lp, and blood leukocytes >100/lp.

Radiological examination consisted of plain abdominal, thoracic and urethrographic photos. Plain abdominal radiograph shows opacity in tubular-shaped metal forming a $\mathrm{T}$ image projected in the pelvic cavity, suggesting a foreign object with metal density (Fig. 1). On the thoracic foto, the heart and lung are in the normal limits (Fig. 2). The urethrographic examination does not show stricture or rupture of the urethra (Fig. 3).

The patient then underwent radiological examination in Surabaya using urethrography (Fig. 3). Pre-operative laboratory tests did not show significant abnormalities. Likewise, thoracic photo examination showed that the heart and lungs were within normal limits. Based on the condition of the patient, we decided to intervene surgically with vesicotomy (Fig. 4).

After vesicotomy, the foreign object was found as a tip of a headset along with twisted cable (Fig. 5). Then, the headset was removed out from the bladder and a $16 \mathrm{fr}$ catheter was installed and stitched in two layers. The mucosa was sutured with plain 3 and the serosa was sutured with vicryl 3.0. Bladder test was performed and did not show leakage. Drain size of $14 \mathrm{fr}$ was installed and bleeding was evaluated.
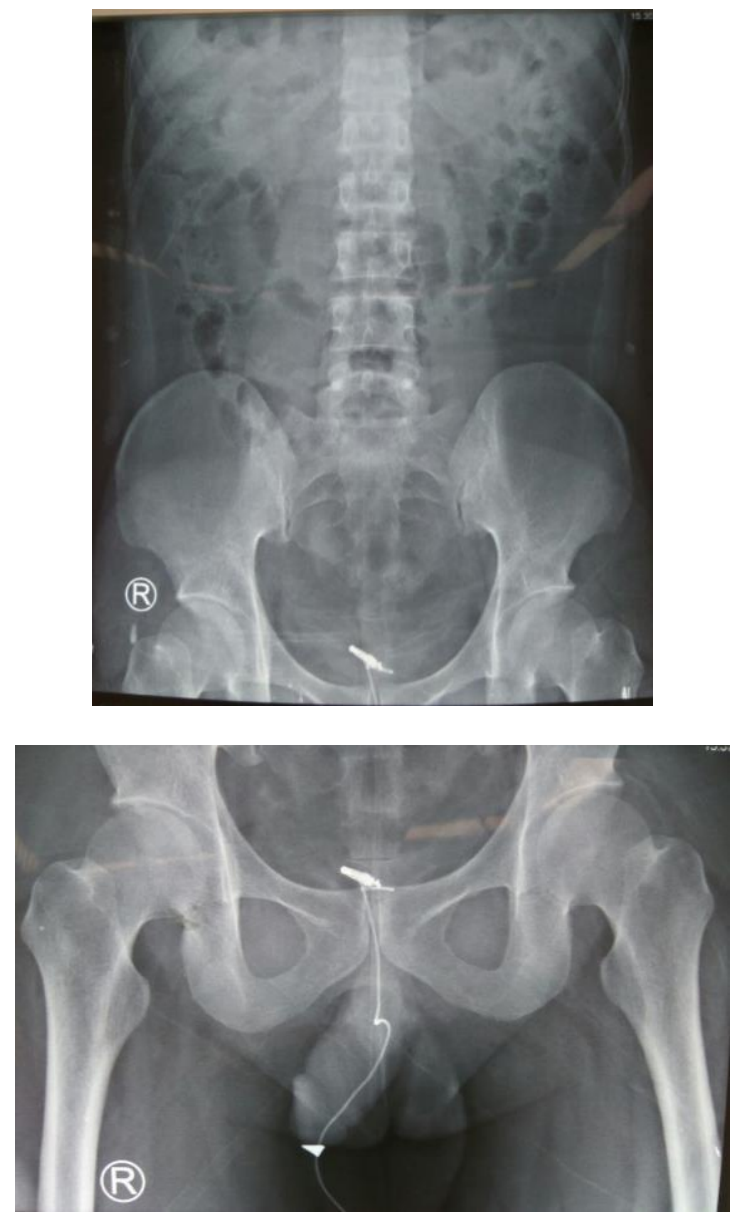

Fig. 1. Plain abdominal radiograph showing a metallic foreign object image in urinary vesicle.

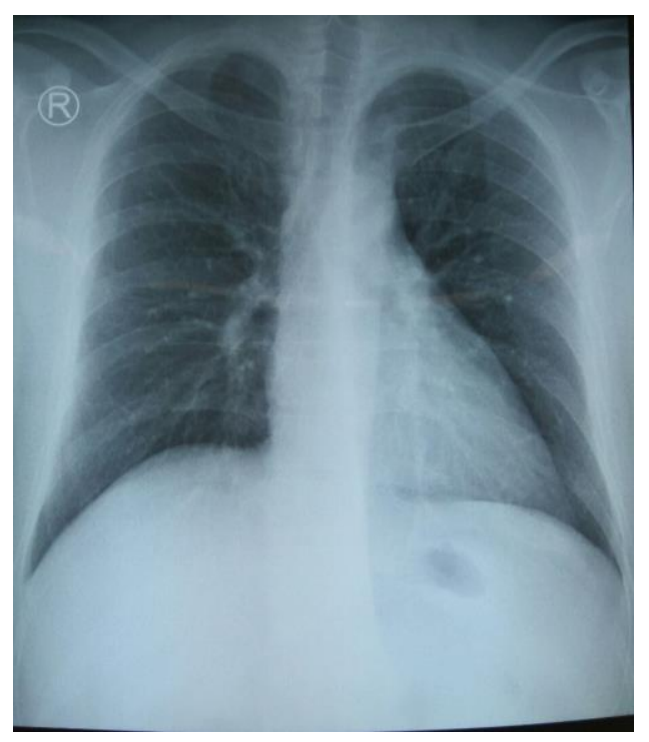

Fig. 2. Thoracic photo showing heart and lungs within normal limits 


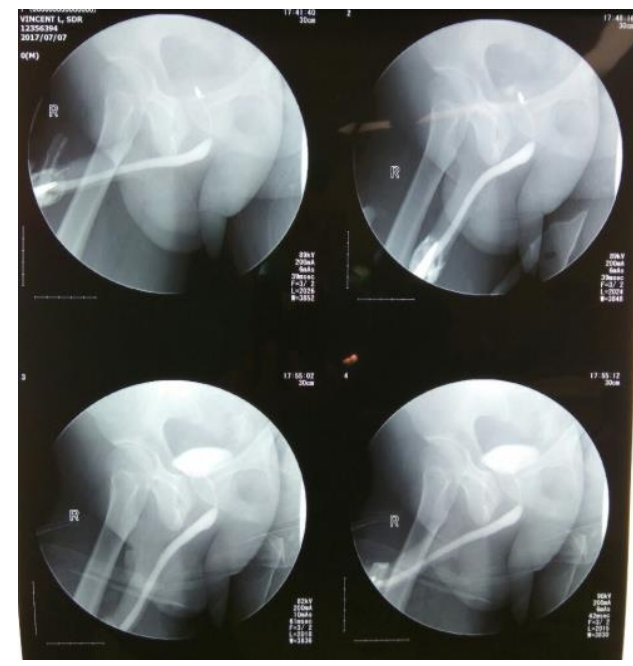

Fig. 3. Urethrography does not show stricture or rupture of the urethra
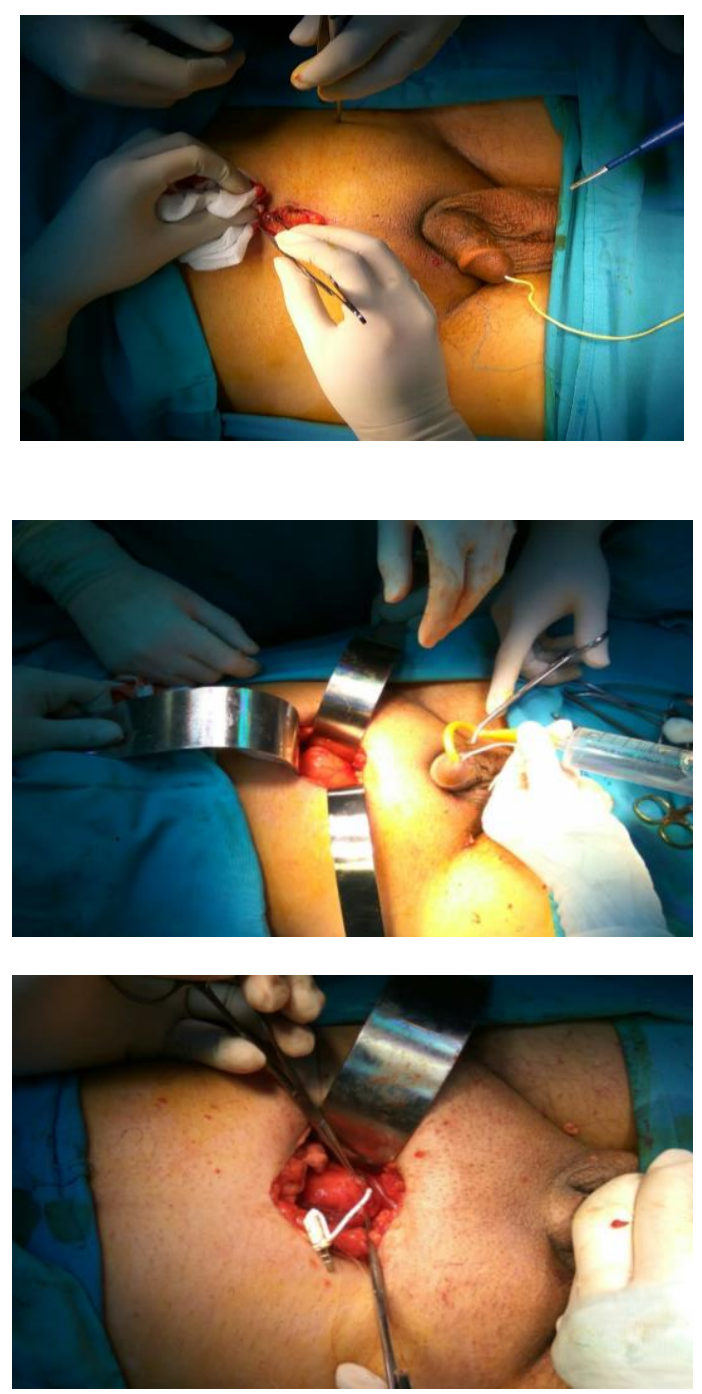

Fig. 4. Open vesicotomy, headset extraction

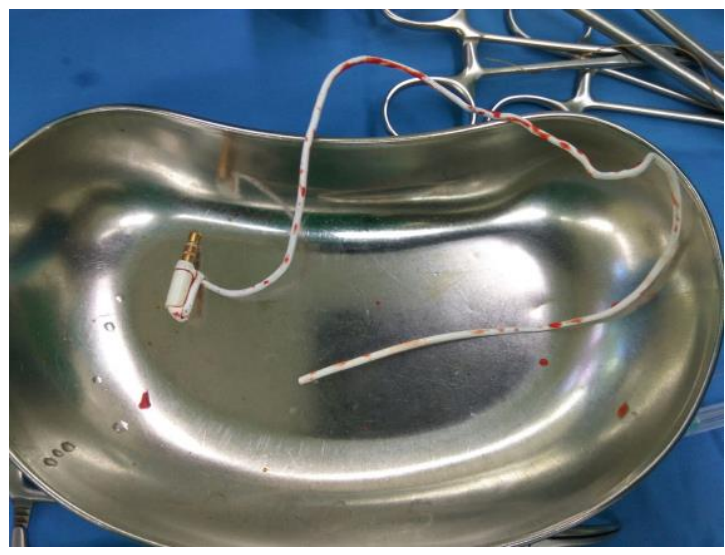

Fig. 5. The tip of the headset after being removed from the bladder

After surgery, the patient was observed to see vital signs, complaints, urine production, and drainage in the room. One day after surgery, drain production was 48 $\mathrm{cc} / 24$ hour hemorrhagic. On the sixth day the drain was released. On the seventh day, after surgery, the patient had been able to mobilize well. Complaint of pain was minimal and no other significant complaints were found. Patients were scheduled to visit the clinic three days later.

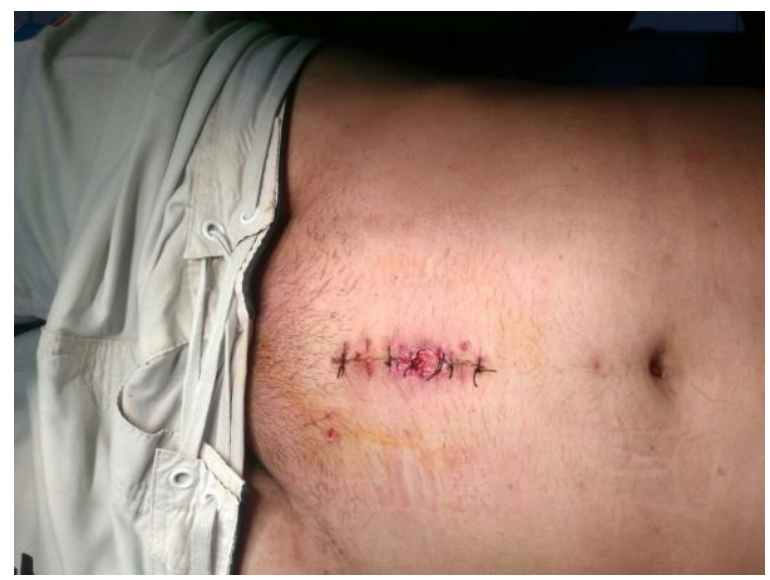

Fig. 6. Vesicotomy surgical wound

On the third day after being discharged from the hospital, the patient visited the clinic and had no complaints of pain in the remans of the surgical wound, no fever, and the wound improved (Fig. 6). The wounds did not indicate the presence of pus.

\section{DISCUSSION}

foreign objects presence in the urogenital tract is a relatively rare pathological incidence. According to Mischianu et al, from many cases, this condition has an 
impact. This is especially true of the bladder, because the urethra and ureter are attached to the catheter for only a certain period of time and with indications of installation. Its presence in the urinary tract predisposes to infection, calculus formation, and obstruction to the bladder neck, all of which can cause kidney damage (Mischianu et al 2007).

Foreign objects in the bladder can occur due to deliberate self-insertion or migration from surrounding organs. The patient does not convey the reason and how he entered the foreign object. This is unusual, because, according to Aliabadi et al, most patients feel ashamed to admit that they have inserted the foreign object for sexual satisfaction, psychological, therapeutic, or other reasons. The patient comes when there are symptoms that getting worse or have complications. With the length of the male urethra, it is not possible for a foreign object to enter itself into the bladder without being known by the patient. According to van Ophoven and de Kernion, the most common cause of people entering foreign objects into the urogenital tract is for sexual or erotic satisfaction. In adults, foreign objects are usually involved for masturbation, which is often associated with mental health disorders, so identification and psychiatric evaluation is needed (Sharma et al 2006, Garcia et al 1999, Izumi et al 2008).

Various foreign objects inserted into or affixed from outside the urogenital tract depends on the imagination that includes all types of objects. These objects vary depending on the level of society, the level of development, the purpose of entering, and the cause. Osca et al reported eight cases of foreign objects inserted into the lower urinary tract treated from 1976 to 1990, of which five were intravesical. Objects found include electrical wires, tweezers, hair pins, picture pins, gravel, and paper clips. Kochakarn and Pummanagura studied 78 patients, and the items included were cotton, tampons, paper clips, and ballpoint covers. Rafique has identified intravesical foreign objects such as copper wires, lead pencils, contraceptives, surgical gauze, and Foley catheter pieces (Trehan et al 2007, Kochakarn \& Pummanagura 2008, Rafique 2008).

Intravesical presence of foreign objects with suspected iatrogenic causes require an examination to diagnose, because foreign objects can remain in the body for a long time before symptoms develop. This duration is the period of transfer from the initial location of insertion until it enters the bladder. For example, Izumi et al reported a case of an acupuncture patient with a $2 \mathrm{~cm}$ bladder stone with a needle core who had symptoms of benign prostatic hyperplasia for 10 years. Another example is a case report by Irisawa et al in a 66-year-old man who underwent rectal surgery 6 years before and then found a surgical needle in the bladder. It is estimated that the needle takes about 6 years to move from the perirectal tissue to the bladder (Irisawa et al 1991).

Symptoms that occur in intravesical foreign objects are very constant and are usually caused by irritation of the bladder, and if the foreign object is large, it will reduce the capacity of the bladder. Hematuria can occur due to trauma resulting from self-manipulation or rough objects that injure the walls of the bladder. These symptoms are most often irritating, but may also be obstructive if a foreign object enters the urethra and this is usually accompanied by a large bloody discharge. Suprapubic pain, pain during urination, and fever can occur in persisting cases (Stravodimos et al 2009)

Various kinds of complications may occur with the presence of foreign objects in the bladder. Foreign objects in the urinary tract increase the risk of urinary tract infections. Such infections are often repeated due to persistent bacteria in the foreign object and sometimes due to non-drainage. The risk of endotoxemia must always be kept in mind during the process of extracting foreign objects. Complications, such as calculus formation, have been widely reported in relation to the migration of intrauterine contraceptives and surgical needles (Jensen \& Walter et al 2007, Ituraide et al 2004, Guvel et al 2001, Dermici et al 2003).

Life-threatening complications from the presence of intravesical foreign objects are rare, but they have happened. Ito et al reported that in 2009 there was one case of intravesical foreign object accompanied by vesicular rupture and invaded the peritoneal area. According to the author, there were only 10 similar cases in Japan at the time of the reporting. Severe infection and obstruction can cause renal insufficiency, while urethral injury during the self-insertion or removal can predispose to the occurrence of urethral stricture (Ito et al 2009, Jacobs et al 2009).

Radiological examination is the subsequent step after suspicion for evaluation of patients with intravesical foreign objects. The level and modalities needed depend on the type of foreign object and the presence or absence of complications. Radiological evaluation is needed to determine the exact size, number, and nature of the foreign objects. Ultrasonography can usually localize foreign objects that enter the bladder and determine the size and number correctly, but cannot evaluate the nature of the object properly. However, plain abdominal X-rays can classify objects into radiopaque and radiolucent, so that they can be used to 
determine their properties broadly, such as the radiopaque metal. When bladder perforation is found, computed tomographic cystography is a reliable diagnostic tool that also requires the addition of the bladder's content. The diagnosis can be confirmed by cystoscopy, and some foreign objects can be successfully removed during the process (Shoab et al 2008, Irekpita et al 2011).

The presence of a foreign object in the bladder is a challenge in the field of urology that requires immediate treatment and must be treated as an emergency. Various techniques used to excrete intravesical foreign objects demonstrate the ability of an urologist to remove them. In general, the techniques used are classified into endoscopic and open surgical approaches. The method used usually depends on the nature and size of the object as well as the operator 's expertise and the availability of equipment. Endoscopic and minimally invasive techniques must be recommended first. However, in many cases, endoscopy cannot be done and the surgical method needs to be applied (Irekpita et al 2011).

A simple endoscopic approach for the extraction of intravesical foreign object is cystoscopy and removal by biopsy forceps. This technique is suitable for small objects such as intrauterine contraception, as reported by Sharma et al (2006) and Forde et al (2009) in different studies. A more complex sistoscopic approach has been explained by Reddy and Daniel. Cystoscopy is used as an optical device and a laparoscopic port is inserted suprapubically in the visual field for complex foreign object extraction, while the bladder is insulated with carbon dioxide. Laparoscopic approach for the removal has also been described. If there is encrustation or stone formation in the foreign object, lithotripsy or stone forceps can be used to destroy stones and take stone fragments so as to facilitate the extraction of foreign object. Sometimes, open surgery is needed because the foreign object is too large or the nature of the foreign object requires it, as in the case of our patients. This might also be done if the human resources or the equipments are not available (Irekpita et al 2011, Forde et al 2009, Reddy \& Daniel 2004, Jung et al 2008).

Surgical approach in patients treated with vesicotomy is aimed at foreign object extraction, in this case the headset cable since the plain abdominal photo (Fig. 1) showed that the end of the headset cable was in a crossing position so that it was difficult to manipulate the headset out by pulling it from the tip of the penis. If the headset had been pulled forcefully, it must have caused trauma to the urethra, and, as explained earlier, uretrography did not show urethral rupture and stricture (Fig. 3)

Patient could go home after the pain reduced, the production of drain became minimal, and the patient has been able to mobilize well. To the patient we also explained the effects of re-inserting foreign objects into the bladder. The patient came every 3 days for wound care after surgery.

\section{CONCLUSION}

The presence of foreign objects in the urogenital tract is a pathological incidence that is relatively rare, and, according to Mischianu et al, from many cases, such presence does have an impact. This is especially true of the bladder, because catheter may only be installed for a certain period of time with an indication of the installation. Its presence in the urinary tract predisposes to infection, calculus formation, and obstruction to the bladder neck, all of which can cause kidney damage.

The surgical approach to the patient we treated by performing vesicotomy aimed to extract foreign objects in the form of a headset cable because on a plain abdominal photo the end of the headset cable was in crossing position, so that it was difficult to manipulate the headset out of the penis. If the pulling out had been done forcefully, trauma to the urethra must had been occurred, and, as explained earlier, uretrography did not show rupture and stricture in the urethra.

\section{REFERENCES}

Dermici D, Ekmekcioglu O, Demitras A, Gulmez I (2003). Big bladder stones around an intravesical migrated intrauterine contraceptive device. IntUrol Nephrol 35, 495-496

Eke N, Okpani AO (2003). Extra uterine traslocated contraceptive device:a presentation of five cases and revisit enigmatic issues of iatrogenic perforation and migration. Afr J Reprod Health 7, 117-1123

Forde JC, Casey RG, Grainger R (2009). An unusual penpal: case report and literature review of posterior urethral injuries secondary to foreign body insertion. Can J Urol 16, 4757-4759

Garcia RV, Vareal SM, Fernandez GL (1999). Urethra foreign bodies: apropos 2 cases. Arch Esp Urol 52, 7476

Guvel S, Tekin MI, Kiliac F, et al (2001). Bladder stones around a migrated and missed intrauterine contraceptive device. Int J Urol 8, 78-79

Irisawa C, Yamaguichi O, Shiraiwa Y, et al (1991). A case of a foreign body in the urinary bladder-surgical 
suture needle was found in the urinary bladder. Hinyokika Kiyo 37, 154-159

Ito H, Ninomiya A, Furuuchi J, et al (2009). A case of intravesical foreign body with a vesical rupture invading the peritoneal cavity: a case report. Hinyokika Kiyo 55, 425-427

Ituraide CA, Goza LF, Beyries TW, et al (2004). Double bladder lithiasis from an intrauterine device: report one case. Arch ESP Urol 57, 160-162

Izumi K, Takizawa A, Udagawa K, et al (2008). Bladder stone secondary to migration of an acupuncture needle. Hinyokika Kiyo 2008 54, 365367

Jacobs BL, Matoka DJ, Maranchie JK (2009). Renal insufficiency secondary to delayed presentation of a retained foreign body. Can J Urol 16, 4697-4700

Jensen CS, Walter S (2007). Urinary tract infections: occurrence, causes and prevention. Ugeskr Laeger 169, 4265-4268

Jung US, Lee JH, Kyung MS, et al (2008). Laparoscopic removal of an intravesical foreign body after laparascopically assisted vaginal hysterectomy,a case report and review of the literature. Surg Laparosc Endosc Percutan Tech 18, 420-427

Kochakarn W, Pummanagura W (2008). Foreign bodies in the female urinary bladder: 20-year experience in ramathibodi hospital. Asian Journal of Surgery 31, 130-133

Mischianu D, Ilie CP, Madan V, et al (2007). Foreign bodies in the urogenital tract-between iatrogeny and autoerotism. Chirurgia (Bucur) 102, 699-707

Rafique M (2008). Intravesical foreign bodies: review and current management strategies. Urology Journal 5, 223-231

Reddy BS, Daniel RD (2004). A novel laparoscopic technique for removal of foreign bodies from urinary bladder using carbondioxide insufflation.Surg laparosc Endosc Percutan Tech 14, 238-239

Sharma UK, Rauniyar D, Shar WF (2006). Intravesical foreign body: case report. Kathmandu Univ Med J 4, 342-344

Shoab RF, Anwar F, Barron D (2008). Foreign body in the urinary bladder:early CT cystogram is investigation of choice. Pak Med Assoc 58, 277-278

Stravodimos KG, Koritsiadis G, Koutalellis G (2009). Electric wire as foreign body in a male urethra: a case report. J Med Case Report 3, 49

Trehan RK, Haroon A, Memon S, Turna D (2007). Successful removal of a telephone cable, a foreign body through the urethra into the bladder: a case report. J Med case Reports 1, 153 